\title{
Analysis of Mustahik Welfare Effect in Bandar Lampung City through Zakat Policy and Zakat Administration
}

\author{
Indah Hermiati ${ }^{\mathrm{a}, 1, *}$, Budi Puspo Priyadi ${ }^{\mathrm{b}, 2}$, Sundarso $^{\mathrm{b}, 3}$ \\ 1,2,3 Faculty of Social Science and Political Science, Diponegoro University (50241), Indonesia \\ ${ }^{1}$ Email: indahhermiati20@gmail.com*; ${ }^{2}$ Email: budipuspo@gmail.com; ${ }^{3}$ Email: sundarso232@gmail.com \\ * corresponding author
}

\section{ARTICLE INFO}

Article history

Received 2020-08-29

Revised 2020-09-12

Accepted 2020-09-19

Keywords

Poverty, Policy, Administration, Zakat, Welfare

\begin{abstract}
Poverty can cause economic inequality if it is not handled appropriately in Islam poverty is near to kufr. One strategic role as an instrument to reduce poverty and disagreement in Islam is through zakat. The research objective is to study the zakat policy and zakat administration on mustahik welfare in Bandar Lampung City. Methods of this study using a quantitative method with multiple linear regression analysis techniques. The number of research samples were 37 respondents. Based on the results of research simultaneously shows that the zakat policy and zakat administration determine the significance of welfare while partial shows the zakat policy does not significantly oppose the administration of zakat significant on welfare.
\end{abstract}

\section{INTRODUCTION}

Poverty is a problem that can affect the level of welfare of a country, one of which is Indonesia. BPS data shows the percentage of poverty in Indonesia is still high wherein 2018 it was 10.81 percent and 2019 it was 10.46 percent. Based on BPS data, there are ten provinces with the highest percentage of poverty in 2018, one of them is Lampung Province, which is 13.14 percent. The mother city of Lampung Province is Bandar Lampung with a percentage of poverty, which is 9.04 percent. (BPS.go, id, 2018 - 2019).

The Millennium Development Goals (MDGs) aim to target poverty reduction of up to 7.5 percent of the total population BPS data shows the percentage of poverty in Indonesia is still high wherein 2018 it was the number is declining, however a global target is still far to be accomplished because the level of poverty in Indonesia is still high. Ishaq (inSolikatun et al., 2014) stated one of the reasons why the problem of poverty alleviation just occurred because both the state and the organization still ignored the spiritual values, beliefs, and local culture. According to (Beik, 2013)The economic regulations established by the government are still based on conventional economics that ignores spiritual values. The facts in the field show that not all people get welfare, whereas welfare is one aspect that is expected by all citizens(Nafiah, 2015).

Based on Islamic teachings, zakat has an important role in the economy. Zakat does not only get legitimacy from the government, but also from religion that aims to alleviate poverty, maximize the potential of human resources, increase productivity, and community income (Azwar, 2016). Indonesia has great potential, reaching Rp. 217 trillion, where the realization of this potential will largely depend on professional and trusted zakat institutions(Firdaus et al., 2012). Research on thepotential of zakat is carried out by(Qardawi inBeik, 2016)stated that zakat has great potential that can be optimized for development in overcoming the problem of poverty and income inequality.

Government policy instruments related to zakat as stipulated in Act Number 23 of 2011 concerning Management of Zakat (Beik, 2009). The existence of rules relating to the management of zakat issued by the government is expected to provide certainty and responsibility of amil bodies or zakat institutions in managing and coordinating the interests of stakeholders (Nurhasanah dan Suryani, 2018). According toSarif dkk. (2013) Zakat from a government perspective is a strategic fund that must be explored and developed to improve the economy of Muslims. In the hadith which 
is declared as zakat, the strategic role as an instrument to reduce poverty and agree on opinions.Zakat is a pillar of Islam that must be taken by every Muslim so that no one reduces and is rich in stingy people (narrated by Imam Thabrani). According to Fitri(2017)zakat becomes a means for the community to form cooperation and regulate as a guarantor of social protection. The basic principles and objectives of assisting overcome the standard of living of mustahik, education, and social aspects such as overcoming financial / labor problems and people below the poverty line.

The aim of zakat is divided into two according to (Beik dan Arsyianti, 2016)first consumptively (short term) and second productively (long term). In practice, the distribution of zakat in society is only consumptive zakat which is used to meet daily needs and does not have long-term or permanent goals such as alleviating poverty (Qadir inPratama, 2015).According to Sundari(2019)the use of zakat should not only be consumptive but also productive, namely by providing capital in the form of money or goods to mustahik to be developed which aims not only to meet daily needs, but for the future. Similar research conducted by Wulansari dan Setiawan (2014)giving productive zakat to mustahik aims to increase business capital so that it has added value to support life in the world and to support socio-economic well-being. Mustahik who are given productive zakat funds are people who have businesses that need and are worthy of assistance (Salam dan Risnawati, 2018).

The making of zakat as an instrument of income distribution then the assets obtained are distributed to people in need (mustahik) and must be regulated in a clear zakat management mechanism because the zakat system is run properly and correctly causing no more people who lack and distress (Khumainidan Apriyanto, 2018). Well managed zakat is one of the factors for improving the economic conditions of the community(Khasanah, 2010).With good management, zakat becomes a potential source of funds that is useful for the progress and general welfare (Nopiardo, 2016). By utilizing zakat which is distributed productively it will be more beneficial in the long term.

Zakat management mechanism, namely the establishment of zakat management institutions. BAZNAS is one of the zakat institutions which aims to collect, manage, distribute and utilize zakat. The purpose of establishing zakat institutions is to be clearer and more structured because the most important thing about zakat is how to manage it. Thus, it can be understood that the distribution of zakat should be prioritized to build productive businesses for the recipients of zakat to be able to bring in income for mustahik and even absorb labor. Based on these problems the authors are interested in conducting research related to how the influence of zakat policy and zakat administration on the welfare of mustahik in Bandar Lampung City.

\section{METHOD}

The study was conducted in the city of Bandar Lampung using 37 respondents consisting of 35 mustahik recipients of productive zakat assistance and two BAZNAS parties spread across 14 subdistricts in Bandar Lampung. When the research lasted for two months, the period from March to April 2020. The research method used, namely quantitative. Types and sources of research data consist of primary data obtained from questionnaires and BAZNAS and secondary data obtained from BPS, Outlook and E-Book BAZNAS strategy studies, and articles and journals related to this research.

Methods of data collection using questionnaires, observations, interviews, and documentation. The variables in this study consisted of zakat policy variables $\left(\mathrm{X}_{1}\right)$ of 6 question items, zakat administration variable $\left(\mathrm{X}_{2}\right)$ of 13 question items, and welfare variables $(\mathrm{Y})$ of 7 question items. Data processing methods using a Likert scale with multiple linear regression analysis using SPSS application version 23.0. Testing using multiple linear regression analysis is used to determine the effect of zakat policy variables $\left(\mathrm{X}_{1}\right)$ and zakat administration $\left(\mathrm{X}_{2}\right)$ on welfare $(\mathrm{Y})$ with the following hypothesis formulation:

1. $\mathrm{H}_{0}$ : Accept $\mathrm{H}_{0}$ and reject $\mathrm{H}_{\mathrm{a}}$ means that there is no significant effect between zakat policy variables and zakat administration on the level of public welfare.

2. $\mathrm{H}_{\mathrm{a}}$ : Accept $\mathrm{H}_{\mathrm{a}}$ and reject $\mathrm{H}_{0}$ means that there is a significant effect between zakat policy 
variables and zakat administration on the level of public welfare.

\section{RESULTS AND DISCUSSION}

\section{General Description of Respondents}

Respondents in this study consisted of 35 recipients (mustahik) recipients and from BAZNAS (zakat distributors) 2 respondents, so the total respondents in this study were 37 respondents who had different backgrounds such as education, the amount of funds obtained, and type of business. The distribution of productive zakat is channeled through the "Bandar Lampung prosperous and just" program. This program is more focused on the problem of productive zakat. The main target of the productive zakat program is the provision of venture capital assistance in the form of funds or business goods to community groups or individuals. The following characteristics table Respondents below:

Table 1. Characteristics of Respondents

\begin{tabular}{|c|c|c|}
\hline Type of Characteristics & Number of People & Percentage \\
\hline \multicolumn{3}{|l|}{ Level of Education } \\
\hline Junior High School & 12 & 32,43 \\
\hline Senior High School & 20 & 54,05 \\
\hline Associate Degree & 2 & 5,40 \\
\hline Bachelor Degree/S1 & 1 & 2,70 \\
\hline Master Degree/S2 & 2 & 5,40 \\
\hline \multicolumn{3}{|l|}{ Amount of Funds obtained } \\
\hline Rp. $1.000 .000-2.500 .000$ & 5 & 14,29 \\
\hline Rp. 3.000.000-4.500.000 & 7 & 20,00 \\
\hline Rp. 5.000.000-6.500.000 & 12 & 34,28 \\
\hline Rp. $7.000 .000-8.500 .000$ & 3 & 8,57 \\
\hline$\geq 10.000 .000$ & 8 & 22,86 \\
\hline \multicolumn{3}{|l|}{ Type of Business } \\
\hline Food Stalls & 10 & 28,57 \\
\hline Canteen & 9 & 25,71 \\
\hline Conch craftsman /Brass/Bag & 4 & 11,43 \\
\hline slipper trader & 1 & 2,86 \\
\hline Vegetable/fish traders & 3 & 8,57 \\
\hline Photocopy/Printing & 1 & 2,86 \\
\hline Furniture & 1 & 2,86 \\
\hline Pertamini & 1 & 2,86 \\
\hline The chips business & 2 & 5,71 \\
\hline Buying and selling livestock & 1 & 2,86 \\
\hline Repair Shop & 1 & 2,86 \\
\hline Wreckage & 1 & 2,86 \\
\hline
\end{tabular}

In this study the educational backgrounds of respondents differed and were grouped into 5 categories starting from the Junior High School level there were 12 respondents (32.43 percent), the Senior High Schoollevel there were 20 respondents (54.05 percent), the Associate Degree level there were 2 respondents (5, 40 percent), the level of Bachelor Degree was 1 respondent $(2.70$ percent) and the level of Master Degree was 2 respondents (5.20 percent).

The provision of business capital for productive funds is given according to the type of business and the results of selection from the City of Bandar Lampung BAZNAS. Business capital received by respondents is grouped into 5 categories, namely: the amount of Rp. 1,000,000 2,500,000 as many as 5 respondents (14.29 percent), the amount of Rp. 3,000,000 - 4,500,000 as many as 7 respondents (20.00 percent), the amount of Rp. 5,000,000-6,500,000 as many as 12 respondents (34.28 percent), the amount of Rp. 7,000,000 - 8,500,000 as many as 3 respondents ( 8.57 percent), and the number of $10,000,000$ was as many as 8 respondents ( 22.86 percent).

The types of businesses that are run by mustahik are different, namely: 10 mustahik stalls (28.57 percent), canteen business as many as 9 mustahik ( 25.71 percent), snail/brass/bag craftsmen as much as 4 musthik (11.43 percent ), vegetable/fish traders as much as 3 mustahik (8.57 percent), 
chip business as much as 2 mustahik (5.71 percent) and photocopy/printing business, furniture, pertamini, slipper trader, livestock sales, repair shop, wrecking, respectively 1 mustahik with 1 type of business ( 2.86 percent).

\section{Multiple Linear Regression Test}

To determine the differences in zakat policy variables $\left(\mathrm{X}_{1}\right)$ and zakat administration $\left(\mathrm{X}_{2}\right)$ to welfare $(\mathrm{Y})$ through the multiple linear regression analysis test as follows:

Table 2. Multiple Linear Regression Test Results

\begin{tabular}{ccccc}
\hline Independent Variable & Regression coefficient & $\mathbf{T}_{\text {count }}$ & Sig.t & Ket \\
\hline Constant & $-2,417$ & $-0,201$ & 0,842 & not significant. \\
\hline Zakat Policy $\left(\mathrm{X}_{1}\right)$ & $-0,018$ & $-0,037$ & 0,971 & not significant. \\
\hline $\begin{array}{c}\text { Zakat Administration } \\
\left(\mathrm{X}_{2}\right)\end{array}$ & 0,535 & 2,395 & 0,022 & significant. \\
\hline $\begin{array}{c}\text { Source: data processed SPSS, 2020 } \\
\text { (n) }\end{array}$ & & & &
\end{tabular}

Source: data processed SPSS, 2020

The multiple linear regression test usesthe following equation model:

$$
\begin{aligned}
& \mathbf{Y}=\mathbf{a}+\mathbf{b}_{1} \mathbf{X}_{\mathbf{1}}+\mathbf{b}_{2} \mathbf{X}_{\mathbf{2}}+\mathbf{e} \\
& \mathrm{Y}=-2,417-0,018 \mathrm{X}_{1}+0,535+\mathrm{e}
\end{aligned}
$$

Based on the test results of multiple linear regression equations in table 2 it is known that the constant coefficient of -2.417 this coefficient is negative meaning that if there is no zakat policy variable $\left(\mathrm{X}_{1}\right)$ and zakat administration $\left(\mathrm{X}_{2}\right)$ then Welfare $(\mathrm{Y})$ will decrease by 2,417 or can be interpreted that the value of 2,417 is a value when both variables $\left(\mathrm{X}_{1}\right.$ and $\left.\mathrm{X}_{2}\right)$ are constant.

The results of the zakat policy regression coefficient $\left(X_{1}\right)$ of -0.018 this coefficient is negative, explaining that if the zakat policy $\left(\mathrm{X}_{1}\right)$ decreases, welfare $(\mathrm{Y})$ will decrease by 0.018 . The results of the zakat policy regression coefficient $\left(\mathrm{X}_{2}\right)$ of 0.535 are positive because this coefficient explains that if the administration of zakat $\left(\mathrm{X}_{2}\right)$ increases, welfare $(\mathrm{Y})$ will increase by 0.535 with the condition that other variables are constant.

To see the significant value of the influence between variable $\mathrm{X}$ to $\mathrm{Y}$ is done by comparing the $t_{\text {count }}$ or alfa valuewith the rules or basis for decision making in the t-test as follows: a). if the $t_{\text {count }}<t_{\text {table }}$ or sig.velue $>0,05$ means that it is not significant, and $b$ ). if the $t_{\text {count }}>t_{\text {table }} O$ sig.velue $<$ 0,05 means significant.

Based on table 2 shows the value of Sig.t for the zakat policy variable $\left(X_{1}\right)$ of $0,971>0,05$ means that the zakat policy has no significant effect on the welfare of mustahik while the zakat administration variable $\left(\mathrm{X}_{2}\right)$ has a Sig.t value of $0,022<0,05$ meaning that administration zakat has a significant influence on the welfare of mustahik. The closeness of the relationship between research variables is shown through the coefficient of determination $\left(\mathrm{R}^{2}\right)$ test. The use of the coefficient of determination has a weakness, namely the bias of the number of independent variables included in this model because every addition of the independent variable $\mathrm{R}^{2}$ increases, no matter whether the variable has a significant effect or not on the dependent variable (Ghozali, inHuda dan Ghofur, 2016). In this study to evaluate the best regression model, the researchers used the R Square value as follows:

Table 3. The Coefficient of Determination $X_{1}$ and $X_{2}$ to $Y$ Summary Model

\begin{tabular}{|c|c|c|c|c|}
\hline Model & R & R Square & Adjusted R Square & Std. Error of the Estimate \\
\hline 1 & $.441^{\mathrm{a}}$ & .194 & .147 & 4.45136 \\
\hline
\end{tabular}


Based on table 3 it is known that the value of $\mathrm{R}$ Square is 0.194 or 19.4 percent. This means that the welfare variable $(\mathrm{Y})$ is explained by 19.4 percent by the zakat policy variable $\left(\mathrm{X}_{1}\right)$ and zakat administration $\left(\mathrm{X}_{2}\right)$ while the remaining 80.6 percent is explained by other variables outside the regression equation or not explained in this study.

\section{Simultaneous Hypothesis Test}

This test in multiple linear regression aims to determine the simultaneous effect of the independent variable $(X)$, namely: zakat policy $\left(X_{1}\right)$ and zakat administration $\left(X_{2}\right)$ on the dependent variable(Y), namely: welfare. The basis for decision making for this test is based on the

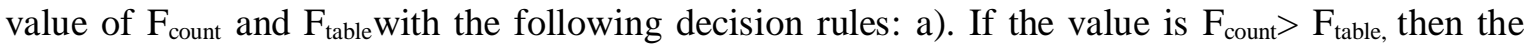
variable $\mathrm{X}$ has a significant effect on the variable $\mathrm{Y}$, and $\mathrm{b}$ ). If the value is $\mathrm{F}_{\text {count }}<\mathrm{F}_{\text {table, then the }}$ variable $X$ has no significant effect on the variable $Y$. To test the hypothesis of the influence between the independent variables $(\mathrm{X})$ and the dependent $(\mathrm{Y})$, the statistical test $\mathrm{F}$ with $\mathrm{F}_{\text {table }}$ in the research of 3.28. The following table explains simultaneously between variables as follows:

Table 4. Test Results $F X_{1}$ and $X_{2}$ to $Y$ ANOVA $^{\mathrm{b}}$

\begin{tabular}{|c|c|c|c|c|c|c|}
\hline & Model & Sum of Squares & Df & Mean Square & $\mathbf{F}$ & Sig. \\
\hline \multirow[t]{3}{*}{1} & Regression & 162.411 & 2 & \multirow{3}{*}{$\begin{array}{l}81.206 \\
19.815\end{array}$} & \multirow[t]{3}{*}{4.098} & \multirow[t]{3}{*}{$.025^{\circ}$} \\
\hline & Residual & 673.697 & 34 & & & \\
\hline & Total & 836.108 & 36 & & & \\
\hline
\end{tabular}

Based on table 4 shows that the $F_{\text {count }}$ is 4,098 with Sig. $F$ is 0,025 . So $F_{\text {count }}>F_{\text {table }}(4,098>$ $3,28)$ and Sig.F $<5$ percent $(0,025<0,05)$. The results of the $F$ test state that the zakat policy variables $\left(\mathrm{X}_{1}\right)$ and zakat administration $\left(\mathrm{X}_{2}\right)$ simultaneously have a significant effect on welfare (Y).

Table 5. The Result of The Linear Regression Summary $X_{1}, X_{2}$

\begin{tabular}{cccc}
\cline { 2 - 3 } & Variable & Beta Coefficient & Influence \\
\cline { 2 - 4 } & ZakatPolicy $\left(\mathrm{X}_{1}\right)$ & 0,241 & Not Dominant \\
\cline { 2 - 4 } Source: Processed & Zakat Administration $\left(\mathrm{X}_{2}\right)$ & 0,444 & Dominant \\
\cline { 2 - 4 } & & &
\end{tabular}

Based on table 5 it can be seen that the variable $X_{2}$ has the greatest beta value, which is 0.444 from the variable $X_{1}$ of 0.241 . This shows that the zakat administration variable $\left(X_{2}\right)$ is dominantly influencing the welfare variable $(\mathrm{Y})$ compared to the variable zakat policy $\left(\mathrm{X}_{1}\right)$. Variable $\mathrm{X}_{2}$ having a positive sign coefficient means that the better the administration of zakat is carried out and implemented, the better the public welfare (mustahik).

\section{Discussion}

This study aims to look at zakat policy and zakat administration on mustahik welfare in Bandar Lampung City. The results of the discussion showed a significant influence between the zakat policy variables $\left(\mathrm{X}_{1}\right)$ and zakat administration $\left(\mathrm{X}_{2}\right)$ on the community welfare variable in Bandar Lampung City simultaneously or simultaneously as indicated by the results $\mathrm{F}_{\text {count }}$ $>\mathrm{F}_{\text {table }}(4,098>3,28)$ and Sig.F $<5 \%(0,025<0,05)$. The results of this $\mathrm{F}$ test state that the zakat policy variable $\left(\mathrm{X}_{1}\right)$ and zakat administration $\left(\mathrm{X}_{2}\right)$ simultaneously have a significant effect on welfare (Y). To find out the contribution of both independent variables to the dependent variable, that is the zakat policy variable $\left(\mathrm{X}_{1}\right)$ and zakat administration $\left(\mathrm{X}_{2}\right)$ to the welfare variable $(\mathrm{Y})$, 
done using R Square. R Square results of 0.194 or 19.4 percent, while the remaining 80.6 percent is explained by other variables outside the regression equation or not explained in this study.

The facts in the field show that the policy has no significant effect due to the weakness of government regulations related to the distribution of productive zakat to those who receive it. Weak government regulations related to sanctions imposed on parties who are not entitled to receive productive zakat. The lack of government socialization related to the policy of providing business capital assistance through productive zakat and the lack of public awareness to pay zakat to institutions appointed by the government so that people distribute traditionally such as mosques.

Research conducted by (Salam dan Risnawati, 2018) supports this finding. This study revealed that productive zakat plays a role as supporting the improvement of the community's economy through the role of zakat administration such as the distribution, management, collection, and utilization of productive zakat funds. The results of other studies that support this research, according to Nurlinda dan Zuhirysan (2019), state that an increase in community welfare will affect through the distribution of ZIS that is productive rather than consumptive.

\section{CONCLUSION}

Based on the results of research and analysis of the influence of zakat policy and zakat administration on the welfare of mustahik in Bandar Lampung City, conclusions can be attracted as follows:

1. The results of data analysis using SPSS multiple linear regression simultaneously stated zakat policy and zakat administrationsignificant effect on welfare because the significant value is smaller than 0,05 , ie 0.025 and was obtained R Square value of 0.194 or 19,4 percent, while the rest to 80,6 percent explained by other variables outside the regression equation or not explained in this study.

2. The results of the research partially showed that zakat policy had no significant effect as seen from the results of the value is $t_{\text {count }}<t_{\text {table }}(1,471<2,032)$ and sig. $(0,14>0,05)$, while the zakat administration has a significant influence on people's welfare in terms of the results of the value is $\mathrm{t}_{\text {count }}<\mathrm{t}_{\text {table }}(2,904>2,032)$ and sig. $(0,006<0,05)$.

3. The analysis shows that the zakat policy is 5.8 percent, and the administration zakat has an effect of 19,4 percent on welfare.

\section{REFERENCES}

Apriyanto, K. (2018). Empowerment. of Earning Zakat Funds Toward the welfare of the People. Vol.2, No.2, 155-164. https://doi.org/10.22236/alurban.

Azwar, M. (2016). Zakat and Social Walfare.Journal ISLAMINOMIC Vol. V. No. 2: 60-74.

Beik, I. S. and Arsyianti, L. Dwi (2016). Measuring Zakat Impact on Poverty and Welfare Using Cibest Model. Journal of Islamic Monetary Economics and Finance, Vol. 1, No.2.

Firdaus, M., Beik, I. S., Irawan, T., and Juanda, B. (2012). Economic Estimation and Determinations of Zakat Potential in Indonesia. IRTI Working Paper Series, WP 143307(August).http://www.isdb.org/irj/go/km/docs/documents/IDBDevelopments/Internet/English/ IRTI/CM/downloads/Working Paper Series/WP-1433-07.pdf.

Fitri, M. (2017).Productive Zakat Management as an Instrument for Improving the Welfare of the People. Economica: Islamic Economics Journal. Vol. 8, No 1: 149-173.

Huda, N., and Ghofur, A. (2016). Analysis of Muzakki Intentions in Paying Professional Zakat. AlIqtishad: Journal of Islamic Economics, 4(2). https://doi.org/10.15408/aiq.v4i2.2547. 
Irfan, Beik, S. (2009).Analysis of the Role of Zakat in Reducing Poverty: Case Study of Dompet Dhuafa Republika. Journal of Thought and Ideas - Vol II.

Khasanah, Umrotul (2010). Modern Zakat Management Instrument for Economic Empowerment of the People. Malang: UIN Maliki Press.

Nafiah, L. (2015).The Effect of Productive Zakat Utilization on Mustahiq Welfare in the Rotating Baznas Program in Gresik Regency. Vol. 5, No.1, ISSN 2252-7907.

Nopiardo, W. (2016).The mechanism of Productive Zakat Management in the Tanah Datar National Amil Zakat Board. JEBI (Journal of Islamic Economics and Business). Vol. 1, No. 2.

Nurhasanah, S., and Suryani, S. (2018).Maximizing the Potential of Zakat Through Increasing Public Awareness. JEBI (Journal of Islamic Economics and Business), 3(2), 185. https://doi.org/10.15548/jebi.v3i2.177.

Nurlinda, and Zuhirysan, M. (2019).Utilization of ZIS in Improving People's Welfare. Al-Amwal, 11(August), 59-70. https://doi.org/10.24235/amwal.v11i1.4227.

Pratama, Y. C. (2015). The role of Zakat in Poverty Prevention (Case Study: Productive Zakat Program at the National Amil Zakat Agency). Tauhidinomics, 1(1), 93-104. https://doi.org/10.15408/THD.V1I1.3327.

Salam, A. and Risnawati (2018). Analysis Productive Zakat to mustahik welfare (Study at Amil Zakat Infaq Shodaqoh Institute NU Yogyakarta). Indonesian Sharia Economics Journal. Vol. VIII, No.2: 96-106.

Sarif, S., Kamri, N. A., and Madun, A. (n.d.). The Impact of Malaysian Islamic Revivalism on Zakat Administration.International Journal of Nusantara Islam. 36-53.

Solikatun, et all. (2008).Poverty in Development. Journal of Chemical Information and Modeling, 53(9), 287. https://doi.org/10.1017/CBO9781107415324.004.

Sundari Tanjung, D. (2019).Effect of Productive Zakat on the City of Medan on the Growth of Business and Welfare Mustahik in East Medan District. AT-TAWASSUTH: Islamic Economics Journal, 4(2), 349. https://doi.org/10.30821/ajei.v4i2.5555.

Wulansari, S. Dwi, and Setiawan, A. Hendra. (2014). Analysis of the Role of Productive Zakat to Mustahik Micro Business Development (Recipient of Zakat). Diponegoro Journal of Economics, 3(1), 1-15. 